\title{
Clavulinopsis fusiformis, a new record for Turkish mycobiota
}

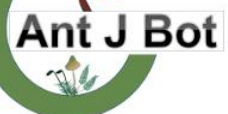

Received : 11.07.2021

Accepted : 03.08.2021

Online : $: 22.08 .2021$
Ali KELEŞ ${ }^{1 *} \odot$, Abdullah KAYA ${ }^{2} \odot$

${ }^{1}$ Yüzüncü Yll University, Education Faculty, Dept. of Mathematics and Science Education, 65080 Van, Turkey

${ }^{2}$ Gazi University, Science Faculty, Department of Biology, 06560 Ankara, Turkey

*alikeles61@hotmail.com, ${ }^{2}$ kayaabd@hotmail.com

\section{Clavulinopsis fusiformis, Türkiye mikobiyotası için yeni bir kayıt}

Abstract: Clavulinopsis fusiformis (Sowerby) Corner. is reported for the first time for the mycobiota of Turkey. This species is the fourth member of the genus Clavulinopsis Overeem in Turkey and characterized by its yellow and fasciculated fruit bodies, ellipsoid to subglobose or globose, one to multi-guttulate basidiospores with a distinct apiculus, and the presence of clamp connection at the base of basidia. The collected sample is described briefly and the photographs related to its macro and micromorphologies were provided.

Key words: Agaricales, Basidiomycota, biodiversity, new record, taxonomy

Özet: Clavulinopsis fusiformis (Sowerby) Corner. Türkiye mikobiyotası için ilk kez rapor edilmiştir. Bu tür Clavulinopsis Overeem cinsinin Türkiye' deki dördüncü üyesidir, ve sarı ve fasikül halindeki gövdesi, elipsoit, küremsiye yakın veya küremsi, tek veya çok damlacıklı, belirgin apikulusa sahip bazidiyosporlar ve bazidiyumların tabanında kulplu bağlantı ile karakterizedir. Toplanan örnek kısaca betimlenmiş ve makro ve mikromorfolojilerine ilişkin fotoğrafları verilmiştir.

Anahtar Kelimeler: Agaricales, Basidiomycota, biyoçeşitlilik, yeni kayıt, taksonomi

Citation: Keleş A, Kaya A (2021). Clavulinopsis fusiformis, a new record for Turkish mycobiota. Anatolian Journal of Botany 5(2): 98-101.

\section{Introduction}

Clavulinopsis Overeem is a genus of coral fungi in the family Clavariaceae. It was first established by Casper van Overeem (1923). Members of the genus are widespread (Kirk et al., 2008) and characterized by yellow, orange or beige coloured, simple or regularly dichotomously branched, cylindric or fusoid stem with obtuse, inflated or cylindric, thin-walled hypha with clamps, truncate or attenuated apex, 2-4 spored basidia with clamps at the base, and smooth or echinulate spores often with big oil drop (Knudsen and Vesterholt, 2018; Petersen, 1969).

Kirk et al. (2008) reports the existence of 33 species, but Index Fungorum (2021) lists 68 conformed Clavulinopsis species, three of which, C. corniculata (Schaeff.: Fr.) Corner, $C$. helvola (Pers.) Corner and $C$. umbrinella (Sacc.) Corner, were also reported from Turkey (Vlaev, 1915; Pekşen and Karaca, 2003; Doğan et al., 2005; Yağız et al., 2005; Solak et al., 2015).

But the current checklist (Sesli et al., 2020) and the latest contributions (Allı et al., 2019; Yakar et al., 2019; Y1ldız et al., 2019; Akçay, 2020; Yeşil et al., 2020; Acar et al., 2021; Doğan, 2021; Kaygusuz et al., 2021; Sesli, 2021; Uzun, 2021) on Turkish mycobiota indicate that, C. fusiformis hasn't been reported from Turkey before.

The study aims to make a contribution to the mycobiota of Turkey.

\section{Materials and Method}

The basidiocarps of $C$. fusiformis were collected during a routine field study in İyidere district of Rize province. Color photographs of the fruit bodies were taken in the field and ecological properties were recorded. Then the samples were collected and transferred to the fungarium within paper boxes. The samples were dried in an air conditioned room and prepared as fungarium material. Investigations were performed under a Leica trinocular microscope by preparing slides from dry specimens. Photographs related to micromorphology were obtained through a Leica ICC50HD digital camera. Identification was performed with the help of

Breitenbach and Kränzlin (1986), Ellis and Ellis (1990), Jordan (1995), Bessette et al. (2007), Kuo and Methven (2014). Furtado et al. (2016) and Acharya et al (2017).

The specimens are kept at Van Yüzüncü Y1l University Herbarium (VANF).

\section{Results}

Fungi R.T. Moore

Basidiomycota R.T. Moore

Agaricales Underw.

Clavariaceae Chevall

Clavulinopsis fusiformis (Sowerby) Corner, Monograph of Clavaria and allied Genera, (Annals of Botany Memoirs No. 1): 367 (1950)

Syn: [Cavlaria ceranoides Pers., Clavaria compressa Schwein., Clavaria fusiformis Sowerby, Clavaria fusiformis f. aurantiaca S. Imai, Clavaria fusiformis var. ceranoides W.G. Sm., Clavaria fusiformis var. congoensis Beeli, Clavaria inaequalis var. fusiformis (Sowerby) Fr., Clavaria platyclada Peck, Bull. Clavulinopsis fusiformis var. bispora K.S. Thind \& Sharda, Ramaria ceranoides (Pers.) Gray, Ramariopsis fusiformis (Sowerby) R.H. Petersen]

Macroscopic and microscopic features: Basidiocarps 65 $130 \times 4-9 \mathrm{~mm}$, cylindrical to slenderly fusiform, usually 
twisted and pointed at the apex, some flattening or compressed with longitudinal grooves, surface smooth, bright to pale yellow, fading with age, somewhat darker toward the base and brownish at the tips at maturity (Fig 1). Flesh yellow, fragile. Taste somewhat bitter, odor not distinctive. Basidia $45-58 \times 6.5-8 \mu \mathrm{m}$, slenderly clavate to subclavate, almost hyaline, with 2-4 sterigmata of 5.5-7 $\mu \mathrm{m}$ long (Fig 2a), clamps present. Basidiospores 5.5-8.2 × 5$7.7 \mu \mathrm{m}$, broadly ellipsoid, subglobose to almost sub- spherical, smooth, with drops or a large guttule and a prominent apiculus (Fig 2b).

Clavulinopsis fusiformis was reported to grow gregariously or in dense clusters with fused bases, on soil among grass or mosses, in poor meadows, grassland or in woods under hardwoods, conifers or shrubs (Breitenbach and Kränzlin, 1986; Buczacki, 1989; Ellis and Ellis, 1990; Jordan, 1995; Bessette et al., 2007, Acharya et al., 2017; Knudsen and Vesterholt, 2018).

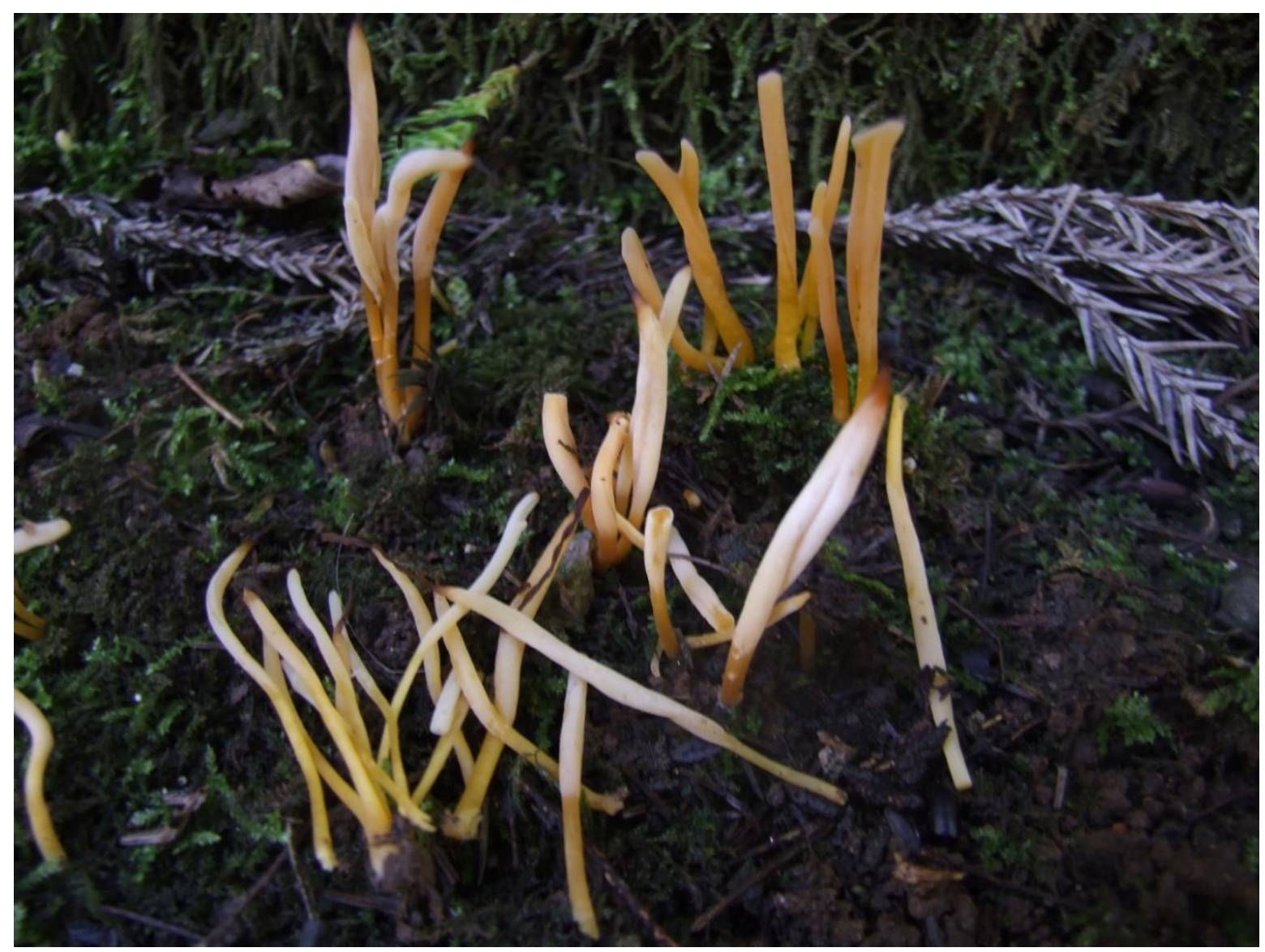

Figure 1. Basidiocarps of Clavulinopsis fusiformis

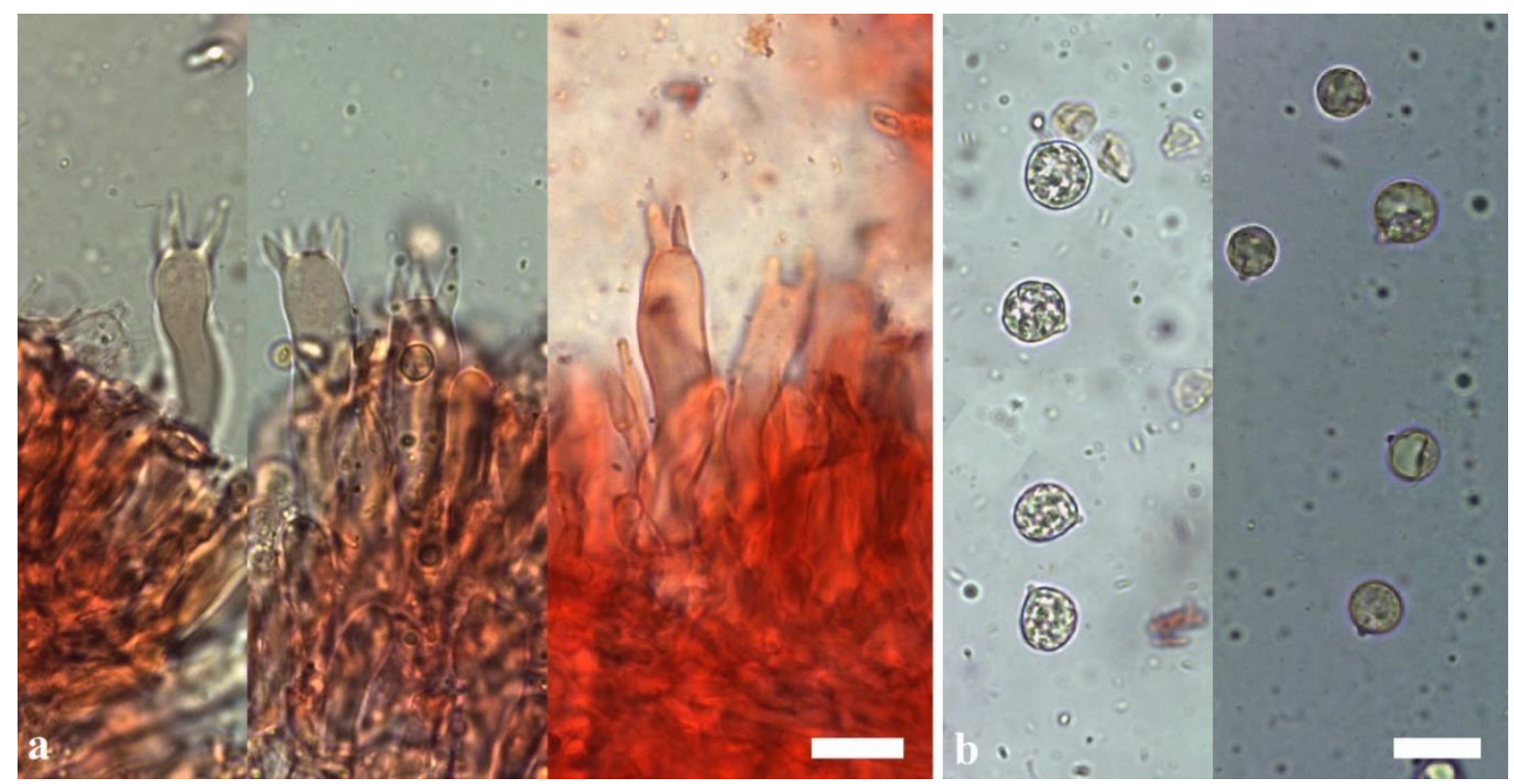

Figure 2. Basidia (a), and basidospores (b) of Clavulinopsis fusiformis (bars: $10 \mu \mathrm{m}$ ) (a: kongo red; b: water) 
Specimens examined: Rize, İyidere, Denizgören village, Cami cemetery, on soil among mosses in coniferous forest., $40^{\circ} 58^{\prime} 408 \mathrm{~N}, 40^{\circ} 22^{\prime} 351 \mathrm{E}, 118 \mathrm{~m}, 14.11 .2015$, AK. 2998.

\section{Discussions}

Clavulinopsis fusiformis was given as new record for Turkish mycobiota as the fourth member of the genus Clavulinopsis. In general, macro and micromorphology are in agreement with those given in literature (Breitenbach and Kränzlin, 1986; Buczacki, 1989; Ellis and Ellis, 1990; Jordan, 1995; Bessette et al., 2007, Acharya et al., 2017; Knudsen and Vesterholt, 2018).

Though Breitenbach and Kränzlin (1986) and Jordan (1995) give the spore size of $C$. fusiformis up to $6.5 \times 6 \mu \mathrm{m}$, but we measured them up to $8.2 \times 7.7 \mu \mathrm{m}$. Bessete et al. (2007) and Knudsen and Vesterhold (2018) also give the spore size up to $9 \times 9 \mu \mathrm{m}$.

Clavulinopsis fusiformis is often confused with $C$. laeticolor (Berk. \& M.A. Curtis) R.H. Petersen. But some macro and micromorphological characters differentiate these two species. Clavulinopsis fusiformis is typically yellow while $C$. laeticolor is usually some shade of orange. Clavulinopsis laeticolor is usually mild in taste, while $C$. fusiformisis typically bitter. Spores of C. laeticolor are subglobose to pyriforme while those of $C$. fusiformis spores are subglobose to almost spherical (Desjardin et al., 2014).

Lincoff (1981), Russel (2006) and Bessette et al. (2007) reports $C$. fusiformis as an edible species. But local people know it as an inedible fungus.

\section{Conflict of Interest}

Authors have declared no conflict of interest.

\section{Authors' Contributions}

The authors contributed equally.

\section{Acknowledgments}

The authors would like to thank Yüzüncü Yıl University Research Fund (215 EBE 254) for its financial support.

\section{References}

Acar İ, Uzun Y, Kalmer A, Dizkırcı AT, Öğün Y (2021). A new record for Turkish mycobiota from Selim (Kars) district. The Journal of Fungus 12(1): 65-70.

Acharya K, Paloi S, Pradhan P, Dutta AK, Chakrabotry N, Roy A (2017). Contribution to the macromycetes of West Bengal, India: 1-7. Research Journal of Pharmaceutical, Biological and Chemical Sciences 8(1): 1229- 1238.

Akçay ME (2020). A new record for the Mycota of Turkey. Anatolian Journal of Botany 4(1): 8-10.

Allı H, Tevlim G, Şen İ (2019). A new record for Turkey's mycobiota from an interestıng habitat iin the Muğla province: Hortiboletus bubalinus (Oolbekk. \& Duin) L. Albert \& Dima. Mugla Journal of Science and Technology 5(1): 114-118.

Bessette AE, Roody WC, Bessette AR, Dunaway DL (2007). Mushrooms of the Southeastern United States. New York: Syracuse University Press.

Breitenbach J, Kränzlin F (1986). Fungi of Switzerland, Vol.2. Lucerne: Verlag Mykologia

Buczacki S (1989). Mushrooms and toadstools of Britain and Europe. Glasgow: Harper Collins Publishers.

Desjardin DE, Wood MG, Stevens FA (2014). California mushrooms, the comprehensive identification guide. London: Timber Press Inc.

Doğan HH (2021). A new truffle species addition, Tuber macrosporum Vittad., to Turkish mycota. Trakya University Journal of Natural Sciences, 22(2): (in print)

Doğan HH, Öztürk C, Kaşık G, Aktaş S (2005). A checklist of Aphyllophorales of Turkey. Pakistan Journal of Botany 37(2): 459485.

Ellis MB, Ellis JP (1990). Fungi without gills (Hymenomycetes and Gasteromycetes), an identification handbook. London: Chapman and Hall.

Furtado AM, Daniels PP, Neves MA (2016). New species and new records of Clavariaceae (Agaricales) from Brazil. Phytotaxa 253(1): 001-026.

Index Fungorum. (2021). http://www.indexfungorum.org/names/Names.asp / [07 July 2021].

Jordan M (1995). The encyclopedia of fungi on Britain and Europe. Devon: David \& Charles Book

Kaygusuz O, Türkekul İ, Knudsen H, Menolli N (2021). Volvopluteus and Pluteus section Pluteus (Agaricales: Pluteaceae) in Turkey based on morphological and molecular data. Turkish Journal of Botany 45(3): 224-242.

Kirk PM, Cannon PF, Minter DW, Stalpers JA (2008). Dictionary of the Fungi, 10th ed., Wallingford: CAB International.

Knudsen H, Vesterholt J (2018). Funga Nordica, Agaricoid, boletoid, clavarioid, cyphelloid and gastroid genera. Copenhagen: Nordswamp.

Kuo M, Methven AS (2014). Mushrooms of the Midwest. Urbana: University of Illinois Press.

Lincoff HG (1981). Field guide to North American mushrooms. New York: Alfred A. Knopf.

Overeem C. van (1923). "Beiträge zur pilzflora von Niederländisch Indien". Bulletin du Jardin botanique de Buitenzorg (in German). 3 (3): $247-96$.

Pekşen A, Karaca G (2003). Macrofungi of Samsun Province. Turkish Journal of Botany 27(3): 173-184.

Petersen RH (1969). The genus Clavulinopsis in North America. Taxon 18(5): 574-575. 
Russel B (2006). Field guide to wild mushrooms of Pennsylvania and the Mid-Atlantic. Pennsylvania: The Pennsylvania State University.

Sesli E (2021). First Records of Cortinarius leucoluteolus and C. roseocastaneus from Turkey. The Journal of Fungus 12(1): 1518.

Sesli E, Asan A, Selçuk F. (edlr.) Abacı Günyar Ö, Akata I, Akgül H, Aktaş S, Alkan S, Allı H, Aydoğdu H, Berikten D, Demirel K, Demirel R, Doğan HH, Erdoğdu M, Ergül CC, Eroğlu G, Giray G, Halikî Uztan A, Kabaktepe Ş, Kadaifçiler D, Kalyoncu F, Karaltı İ, Kaşık G, Kaya A, Keleş A, Kırbağ S, Kıvanç M, Ocak İ, Ökten S, Özkale E, Öztürk C, Sevindik M, Şen B, Şen İ, Türkekul İ, Ulukapı M, Uzun Ya, Uzun Yu, Yoltaş A (2020). Türkiye mantarları listesi. Ali Nihat Gökyiğit Vakfı Yayını. İstanbul.

Solak MH, Işıloğlu M, Kalmış E, Allı H (2015). Macrofungi of Turkey, Checklist, Vol. 2. İzmir, Turkey: Üniversiteliler Ofset.

Uzun Y (2021). Spathularia nigripes and Trichoglossum walteri newly recorded from Turkey. Mycotaxon 136(1): 229-234.

Vlaev K (1915). Contribution to the higher fungus flora of Turkish Thrace. Travaux de la Société Bulgare des Sciences Naturelles 8: 199-207.

Yağız D, Afyon A, Konuk M (2005). The macrofungi of Karabük Province. Turkish Journal of Botany 29(5): 345-353.

Yakar S, Uzun Y, Çevik FT (2019). New locality records for two hypogeous basidiomycete species in Turkey. Anatolian Journal of Botany 3(1): 28-33.

Yeşil A, Uzun Y, Akçay ME, Sadullahoğlu C, Acar İ (2020). Siirt (merkez) yöresinde belirlenen makromantarlar. Yüzüncü Yıl Üniversitesi Fen Bilimleri Enstitüsü Dergisi 25(1): 32-40.

Yıldız MS, Türkekul İ, Işık H (2019). Macrofungal biodiversity of Pazar (Tokat) district. BEÜ Journal of Science 8(2): 387-395. 